AIDS

\title{
New centres for clinical trials
}

\section{Washington}

As the number of cases of acquired immune deficiency syndrome (AIDS) continues to snowball, finding an effective therapy becomes increasingly urgent. The US National Institute of Allergy and Infectious Diseases (NIAID) announced last week that it was committing $\$ 100 \mathrm{mil}$ lion over the next five years to speed the search for a therapy.

Fourteen AIDS treatment evaluation units will be set up around the United States to test drugs that have shown some promise, either by blocking replication of the virus that causes AIDS, or by strengthening immune system function. Therapies likely to be tested in the first year of trials include the anti-viral compounds azidothymidine, foscarnet, HPA-23, ribavirin, interferon-alpha and possibly dideoxycitidine. In announcing the new units, Anthony Fauci, director of NIAID, said a successful treatment would probably combine an anti-viral drug with an immune modulator. But combination therapies will be tested only after each single agent is tested.

A Data Safety Monitoring Board will evaluate the progress at each centre recommending new directions on initial results. To streamline exchange of information among the 14 units, NIAID plans to award a contract this September for a trial coordinating centre.

While Fauci estimates that some 2,000 patients will be included in trials by the end of the first year of the programme, the centres are not intended for treatment of the nearly 22,000 people with AIDS in the United States. Plans for placebo-controlled clinical trials has renewed the debate over the ethical justification of such an approach. Robert Levine, chairman of the Yale University School of Medicine Institutional Review Board, has suggested that using historical controls may be an "ethically less problematic" research design than placebo controls.

But Walter Dowdle, AIDS coordinator

\section{Centres named}

The fourteen institutions receiving NIAID funds are: Harvard University; John Hopkins University; Memorial Sloan-Kettering Cancer Center; New York University; Stanford University; University of California, Los Angeles; University of California, San Diego; University of California, San Francisco; University of Miami; University of Pittsburgh; University of Rochester; University of Southern California; University of Texas M.D. Anderson Hospital and Tumor Institute; and University of Washington. for the Department of Health and Human Services Public Health Service (PHS), says that controlled trials are the "most compassionate way to go". Dowdle argues that, in the long run, only placebo-controlled trials will show which therapies are truly effective. Dowdle is also sceptical about providing experimental drugs to patients not involved in clinical trials. As no agent has been shown to be safe and effective against the AIDS virus, providing unproven drugs to patients could accelerate the course of their disease.

Critics of the government's response to the AIDS problem say that the present administration has not gone far enough in dealing with the problem. In an occasionally heated congressional hearing last week chaired by Representative Ted Weiss (Democrat, New York), Martin Hirsch of Harvard University testified that it is "a national tragedy that so few patients" are in controlled clinical trials for AIDS therapies. Dowdle and Fauci defended NIAID's plans, but when questioned, Fauci admitted that additional money would allow NIAID to support another five centres whose applications had received favourable reviews. Weiss was quick to insist that PHS should request the money in its 1987 budget. After the hearing, Dowdle said PHS was considering asking for more cash, but no decision had yet been made. Joseph Palca

\section{OECD report}

\section{Sweden number one for research}

SwEDEN "has more to teach than to learn" about research and technology policy, according to a team of distinguished examiners for the Organisation of Economic Cooperation and Development (OECD) whose report on Sweden has just been released*. Swedish industry spends more on research and development per unit of turnover than even Japanese industry, according to the report. Over the past 15 years, Swedish business has raised its receipts from patents sold abroad eightfold - while its payments for foreign technology licences has risen only fourfold.

Despite this success, the examiners complain, Sweden pays university professors only 50 per cent more than it pays university janitors. University posts remain unfilled and there is a danger that the education system will not continue to provide the technically trained manpower that Sweden's established high-technology industry needs. Between 1970 and 1984 , the numbers of doctoral graduates in physics, chemistry and mathematics in Sweden fell 50-75 per cent. OECD lays the blame on a system of loans, repayable after graduation, to cover higher education fees. Loans discourage students from entering research careers. A further degree means further debts, and a doctorate does not lead to higher salaries, or at least not sufficiently high to pay off the extra debt.

Yet Sweden depends on science. Its pharmaceutical and biomedical industry spends $17-18$ per cent of its turnover on research and development. Including government spending, Swedish spending per head of population on biomedical research is higher than that of the United States, the OECD examiners claim.

Swedish communications engineering, environmental research, energy-saving equipment, paper-making technologies and robotics are equally advanced. The use of robots in Swedish industry had reached 29.9 per 10,000 workers by 1981 - the highest in the world, ahead of Japan (13.9 in the same year) and the United States (4.0).

The examiners congratulate Sweden on its enlightened workforce, and the "generally pro-science and technology attitude" in the country. This might be attributed, they suggest, to a strong programme by the national council for planning and coordination of research (FRN) in the schools, teaching children about energy problems, cancer, food and the like, an effort the examiners describe as "unprecedented in OECD countries with the possible exception of Japan".

The level of expenditure aimed at industrial development is now so high, however, that Sweden is in a class of its own, with no other country to learn from. Sweden is itself now an experiment, which other countries will watch with interest, to see the effects of this strategy.

A constant theme throughout this report from OECD, however, is that Sweden must beware of taking its renowned egalitarianism too far, at least in research. Swedish success in biomedicine, for example, is traced to the Nobel prize winner Theodor Svedborg and his successors at Uppsala; and the chemical industry to Nobel himself and precision instrumentation to Hasselblad. "We recommend that allocation of funds be made to individuals of excellence, with far-reaching plans, not to fields... and that high quality results be recognized by easy and substantial funding."

Robert Walgate

*OECD Reviews of National Science and Technology Policies: Sweden (OECD Paris, 1986). The review panel consisted of: Guy Ourisson. director. Institut de Chimie des Substances Naturelles, Gif sur Yvette. France: Walter Zegveld. director. Policy Studies and Information Group. TNO. Delfi. The Netherlands: Derek Denton director. Howard Florey Institute, of Medicine. University of Melbourne. Australia: and Yrjo Toivola managing direcior. Vaisala Oy. Helsinki. Finland. 